\title{
Indirect threats as an illegal speech act
}

\author{
Tanya Karoli Christensen \\ University of Copenhagen
}

\begin{abstract}
This article demonstrates how speech act theory and specifically the notion of felicity conditions can help elucidate the threatening aspects of otherwise vague and unspecific messages. Based on a discussion of language crimes, illegal speech acts and the question of intent, I propose a list of felicity conditions for threats that account for their primary purpose as attempts to intimidate a victim. Examples for discussion are taken from a data set of indirect, written threats extracted from verdicts by Danish higher courts. Contrary to previous claims, it is shown that it is not only possible but linguistically quite straightforward to analyze even indirectly phrased messages as instances of threats.
\end{abstract}

\section{Threatening messages as a crime of language}

The topic for this article is born out of a study of verdicts from the Danish High and Supreme Courts trying threatening messages under section 266 of the Danish Penal Code. ${ }^{1}$ This study revealed that the majority of the written threats had been posed indirectly, a fact that raises questions both about the intent and purpose of the defendants in these cases and about the nature of the cases brought to the highest courts. I will return to the latter point in my conclusion (Section 5).

First, the current section introduces the notion of language crimes as discussed within the expanding field of forensic linguistics (cf. Shuy 1993, Fraser 1998, Solan \& Tiersma 2005) and shows how threats can be phrased both directly and indirectly. Section 2 lays out the defining characteristics

1 This article is based upon perspectives and results presented in an article in Danish coauthored with Marie Bojsen-Møller (Christensen \& Bojsen-Møller 2019). Here, I place a larger focus on speech act theory.

Ken Ramshøj Christensen, Henrik Jørgensen \& Johanna L. Wood (eds.). 2019.

The Sign of the V-Papers in Honour of Sten Vikner. Dept. of English, School of Communication \& Culture, Aarhus University, pp. 113-130, doi:10.7146/aul.348.92. (C) The author(s). 
of threatening messages both in terms of Searlean speech act theory (e.g. Searle 1965, 1979) and in terms of the law. Based on the felicity conditions for promises, a list of felicity conditions for threats is developed in section 3 , and in section 4 a variety of indirect threatening messages are analyzed with a focus on the felicity conditions they appeal to. Contextual factors are considered where available and relevant. Finally, in section 5, I discuss the findings and their possible implications for the judicial system.

\subsection{Forensic linguistics and language crimes}

Forensic linguistics deals with all aspects of language and the law, ranging from the interpretation of contractual terms to analyses of courtroom interaction and to extracting intelligence from ransom notes or threatening messages (for a broad introduction to the field, see Coulthard, Johnson \& Wright 2017). A sub-field examines so-called language crimes (Shuy 1993). Solan and Tiersma explain that these are crimes that can be "committed partially or entirely by means of language" and list such crimes as conspiracy, solicitation, perjury, extortion and threats (2005: 179). Several of these crimes can be committed using speech acts that are otherwise completely legal, such as informing about the layout of a building, or instructing someone in the proper use of a tool. It is when the information or instruction is used as a basis for a criminal act that a language crime has occurred; as when the building in question is a bank and the tool is an explosive device. In other words, it is not the utterances that are criminal but the way they are used to attain illegal goals.

In distinction, there are some speech acts that are criminalized in themselves. We can roughly divide them into transgressions against the norm of speaking truthfully and transgressions against the norm of speaking respectfully. In other words, they are extreme cases of violations of the conversational maxim of quality (Grice 1975) and of general principles of politeness (Brown \& Levinson 1987). I go through a few examples of each below.

\subsection{Illegal speech acts}

Perjury is a prime example of a speech act that is criminalized because the speaker knowingly tells an untruth during testimony (Shuy 2011). It is sometimes called 'lying under oath' but is equally punishable in jurisdictions where witnesses are not sworn in before testimony (as is the case in Denmark, for example). It is no wonder that perjury is sanctioned legally since false information risks derailing criminal investigations, waste pre- 
cious time and resources, and ultimately prevent the capture and just sentence of the guilty party. Outside of the justice system, false statements are not necessarily illegal; it is considered immoral to lie to others but generally it is not a criminal offence. However, the spreading of false information about others is criminalized when used to harm their reputation. This is the illegal speech act of defamation (Shuy 2010).

In some jurisdictions, even the spreading of harmful information that is true is considered legally defamatory. This is the case in Denmark where section 267 in the Penal Code criminalizes utterances that offend someone's honor, while section 268 defines it as an aggravating circumstance if the utterance is untrue. In Denmark, therefore, defamation cases can belong to either or both of the above-mentioned categories of transgressions (against speaking respectfully and against speaking truthfully).

The reason that some forms of disrespectful speech are penalized stems from the notion of civil rights, which include the right to participate freely in political and civil life (Catlin 1993). Such rights are effectively diminished when other members of society believe an individual to be unworthy in some respect. Therefore, many countries have criminalized hate speech, i.e., demeaning or derogatory utterances based on a person's membership of a targeted group, typically an ethnic, religious or sexual minority. In other countries (notably, the US with its first amendment rights), freedom of speech is generally prioritized over the freedom from such verbal targeting. In such cases hate speech will not count as an illegal speech act (the proliferation of online abuse of minorities has made this a hotly debated topic over the past couple of decades (Siegel 1998; Leets 2001; Daniels 2008; Henry 2009)).

In contrast, there appears to be universal agreement that threatening someone with violence or other serious harm is a criminal act. Note that it is the act of threatening that is itself criminalized - it is not necessary for there to be an actual act of violence, too, and if there is, it will be prosecuted as a separate count. While a threat can be performed non-verbally, for instance by pointing a gun at a victim, I focus solely on the speech act of threatening. Importantly, verbal threats can be conveyed both directly and indirectly, as shown below.

\subsection{Direct and indirect threats}

Direct threats often mention both the victim, the type of harm intended to befall the victim, and the threatener as the agent of the harmful act (see examples 1-2). 
(1) We will kill all of you

(excerpt from written letter; Rugala \& Fitzgerald 2003: 779)

(2) IM

GONNA

BOMB

this School@2/23/07

(handwritten on wall of public school; Gales 2010: 1)

Disregarding their level of credibility, we see mention of the type of harm as the fairly unspecific act of killing in (1) and the more precisely defined act of bombing in (2). The intended victims are designated as, again the rather fuzzy group of all of you in (1), and the institutional rather than personal this School in (2). Finally, the threateners as agents are in both cases referred to by first person pronouns, plural we in (1) and singular $I$ in (2). It is not unusual for threateners to use $1 \mathrm{pl}$ we to refer to themselves, even when there is in fact only one person behind the threat, "as if to instill credibility and fear through the invocation of a large and mysterious group" (Simons \& Tunkel 2013: 203). ${ }^{2}$

Indirect threats may leave any of these factors unmentioned or unspecified, as seen in (3-4), and their status as threats can therefore more easily be challenged in a court of law.

(3) If this is how you treat honest dissent then WATCH OUT all of you will reap what you sow (excerpt from email; Gales 2010: 41)

(4) North Korean Leader Kim Jong Un just stated that the "Nuclear Button is on his desk at all times." Will someone from his depleted and food starved regime please inform him that I too have a Nuclear Button, but it is a much bigger \& more powerful one than his, and my Button works! (tweet by US President Donald J. Trump, 2 Jan 2018 ${ }^{3}$ )

2 Note that to my knowledge no systematic quantitative measures of the distribution between singular and plural references to threateners have been reported to date. The few corpus linguistic studies of threatening messages all conflate singular and plural pronouns and only distinguish between 1st, 2nd and 3rd person (Gales 2010, 2015a, 2015b; Nini 2017; Muschalik 2018).

3 https://witter.com/realDonaldTrump/status/948355557022420992 
Note how (3) makes use of two different types of tropes that are almost generic to threats: First the imperative WATCH OUT. On the face of it, this may look like a warning and a defendant will likely claim that it was meant as such. However, warnings differ from threats in at least two respects: the speaker has no impact on the outcome of the situation referred to, and, further, the speaker does not wish for it to happen. The initial conditional clause (If this is how you treat honest dissent) makes it unlikely that this is a benign warning since it serves as a justification for whatever it is the addressee is supposed to watch out for. Second, the biblical proverb you [will] reap what you sow also predicts a just return for some action performed by the addressee. Together, the two tropes do more than simply warn of impeding danger, they threaten the victim with unwanted consequences (because there is no reason to watch out for things you wish for).

In (4), Trump attempts to achieve dominance over Kim Jong Un by implying both that his nuclear arsenal is more powerful than the North Korean regime's and that the North Koreans have not fully developed their nuclear technology yet. First, the size of the Button stands metonymically for the power of the weapons it can deploy, and second, stating that the American button works, invites the inference that the North Korean one does not. So, while none of the threats in (3-4) are direct, semantic and pragmatic analysis lays bare that they are indeed threatening.

\section{Defining threats in speech act theory and in legislation}

In order to give an account of the threat as a speech act, it is necessary to first place it under one of the superordinate categories of speech acts defined in speech act theory and then specify how it differs from similar members of the same category.

\subsection{Speech act theory on threats}

According to Searle's taxonomy of speech acts (Searle 1979), there are five major categories of speech acts under which several more specific types are subsumed, as exemplified in table 1. 


\begin{tabular}{|l|l|}
\hline Category & Examples \\
\hline $\begin{array}{l}\text { Assertives - commit the speaker } \\
\text { in varying degrees to the truth of a } \\
\text { proposition }\end{array}$ & $\begin{array}{l}\text { to inform, to insist, to suggest, to boast, } \\
\text { to complain, etc. }\end{array}$ \\
\hline $\begin{array}{l}\text { Directives - attempt to get the } \\
\text { hearer to perform some action }\end{array}$ & $\begin{array}{l}\text { to ask, to order, to request, to beg, to } \\
\text { invite, to permit, to advise, etc. }\end{array}$ \\
\hline $\begin{array}{l}\text { Commissives - commit the speaker } \\
\text { to a future course of action }\end{array}$ & $\begin{array}{l}\text { to promise, to vow, to swear, to embrace, } \\
\text { to pledge, etc. }\end{array}$ \\
\hline $\begin{array}{l}\text { Expressives - express the psycho- } \\
\text { logical state of the speaker regard- } \\
\text { ing a state of affairs }\end{array}$ & $\begin{array}{l}\text { to congratulate, to apologize, to condole, } \\
\text { to deplore, to welcome, etc. }\end{array}$ \\
\hline $\begin{array}{l}\text { Declarations - brings a state of af- } \\
\text { fairs into existence }\end{array}$ & $\begin{array}{l}\text { "I resign", "I pronounce you husband } \\
\text { and wife", "You're fired", "War is here- } \\
\text { by declared", etc. }\end{array}$ \\
\hline
\end{tabular}

Table 1. Searle's classification of speech acts

In his 1965 article "What is a speech act", Searle - almost as an aside classifies threats as commissives but distinguishes them from a prominent member of that category, namely promises:

One crucial distinction between promises on one hand and threats on the other is that a promise is to do something for you, not to you, but a threat is to do something to you, not for you.

(Searle 2008 [1965]: 11; my italics)

Other scholars have argued that threats belong in the category of directive speech acts (Harris 1984; Gingiss 1986), but this view rests upon the prevalent misconception that threats contain a condition that the addressee is pressed to fulfill (see also Fraser 1998: 167; Limberg 2009: 1376). However, the few detailed corpus linguistic studies performed on threatening messages demonstrate that conditional threats are far from the most common type. Gales (2010: 98) finds that approximately a fourth of the threats in her data set of 470 hand- and typewritten threats from US cases are conditional, a result corroborated by Muschalik's (2018: 63) study of 301 threats reproduced in US verdicts. Nini (2017: 106), reports a result of $37 \%$ conditional threats in a study based on a significantly smaller set of 51 threatening messages. Harris (1984: 249) alleges that "what appears to be an unconditional threat may often mean that the condition is implicit," but as can be seen from examples (1-2) above this is false. There is no implied 
condition in these threats. In other words, there is apparently nothing the victims can do to prevent the threatened action from happening, and, importantly, nothing the threatener wants them to do or deliver (as is the case in stalking cases, ransom cases or robberies where some sort of transaction is the primary purpose of the threat in the first place).

Both conditional and unconditional threats, however, contain what I shall call an 'evil promise', even when it is left vague what kind of harmful act that promise entails, or whether the threatener him/herself will perform the act. Whereas normal, benign promises presuppose that the addressee would want the promised act to be performed, a threat presupposes the opposite. Here it is important to keep in mind that whether the threatened act is realized or not is not central to the function of a threat: the purpose of threatening is intimidation: "Inherent in every threat is the intention to send fear into the addressee" (Fraser 1998: 161).

Indeed, intimidation forms the crux of Fraser's definition of threats as a speech act:

... the speaker must intend to express by way of what is said

1. the intention to personally commit an act (or to see that someone else commits the act);

2. the belief that the results of that act will affect the addressee in an unfavorable way;

3. the intention to intimidate the addressee through the awareness of the intention in 1.

(Fraser 1998: 171)

The illocutionary force of a threat can thus be summed up as an attempt to intimidate an addressee by communicating that the threatener intends some serious harm to befall them. Note that this definition does not require a conditional element. As we shall see below, legislation across Danish, British and American contexts differ in this respect.

\subsection{Legislation on threats}

The Danish Penal Code on threats clearly points to intimidation as a defining criterion:

(5) Whosoever threatens to carry out an illegal speech act in a way that is fit to provoke serious fear in someone for their own or other people's lives, health or wellbeing, shall be penalized by fine or imprisonment 
of up to 2 years. (Danish Penal Code, Chapter 27, § 266; my translation and underlining)

A similar provision is given in the British Offences Against the Person Act 1861 on threats to kill: ${ }^{4}$

(6) A person who without lawful excuse makes to another a threat, intending that that other would fear that it would be carried out, to kill that other or a third person shall be guilty of an offence and liable on conviction on indictment to imprisonment for a term not exceeding ten years. (British Offences Against the Person Act 1861; my underlining).

The American legislation most relevant to the prosecution of threats is Chapter 41 of the United States Code of Law, termed 'Extortion and Threats' (18 USC Ch. 41). No section under Chapter 41 refers to an ability or intention to instill fear in the recipient but such a criterion has nonetheless been discussed several times in American case law (Fuller 2015). In Watts v. United States, the Supreme Court refers to but does not define a 'true threat' (by which is apparently meant one that is uttered seriously and not as hyperbole, fiction, jest or the like). It would take us too far to trace the complicated legal arguments in this and later Supreme Court verdicts, but suffice to say that the American judicial system is concerned more with a defendant's intent in uttering a threat than with the perlocutionary effects it may have. Such a focus on intent may be philosophically sound but leaves courts in the difficult position of having to determine what a defendant's mental state was at the time of communicating a threat. While people's mental state can only be directly experienced and assessed by themselves, defendants cannot be assumed to speak truthfully when facing serious legal consequences of their actions. ${ }^{5}$

Notice that British law also refers explicitly to intention ("intending that that other would fear ..."), while Danish legislation invokes the somewhat more objective notion of a threat's 'fitness' to provoke fear, or what we in speech act terms may call its assumed perlocutionary effect. However, with the exception of involuntary manslaughter, Danish criminal law always requires the prosecution to show that a defendant had the intention (Danish:forscet) to commit a crime. But here again, the specific wording of

4 A section of the Criminal Damage Act of 1971 deals with 'threats to damage or destroy property' and contains the same reference to an intention to frighten someone.

5 My point is not to argue that legislation or the courts should dispense with the notion of intent or mens rea, 'the guilty mind', but simply to point out that the question of intent can be weighed against potential to intimidate. 
the law is important: Danish law specifically criminalizes a threat's potential to intimidate, and not whether a victim actually felt intimidated (Greve et al. 2017: 530-532).

In sum, legal codes criminalizing threats refer to a greater or lesser extent to the intentions of the speaker/writer who on the other hand has very little incentive to admit to an intent to threaten. This makes indirect threats particularly problematic since their vagueness and ambiguity affords the threatener an easy recourse to 'plausible deniability' (Pinker, Nowak \& Lee 2008): defendants can simply claim that they never intended to threaten someone, that they merely warned them of impending danger. Contrary to Fraser's contention that it is "virtually impossible ... to determine with certainty when a threat has been made" (1998: 162), I will demonstrate below that it is often both possible and linguistically straightforward to identify even indirectly phrased threats. To this end, I revisit and revise the set of felicity conditions underlying threats since they are instrumental for a linguistically sound argument that a message is threatening, even when indirectly phrased.

\section{The felicity conditions of threats}

The literature on threatening speech acts contains only few treatments focusing on indirect threats (Gingiss 1986; Al-Shorafat 1988; Yamanaka 1995). They are all based on the Searlean notion of felicity conditions as a diagnostic of which primary illocutionary force an indirect speech act has (Searle 2008 [1965]). The oft-repeated example "Can you reach the salt?" counts as a request, not because it directly formulates a request but because it appeals to one of the preparatory conditions for a request. This condition states that the addressee must be able to perform the requested action - otherwise, it makes no sense to request it. By asking if an addressee can reach the salt, the speaker invokes the preparatory condition and thereby invites the addressee to not only consider whether s/he in fact can perform that act, but rather to actually perform it. The circumspect manner of requesting by asking is of course considered politer than requesting by ordering, as in "Hand me the salt!" (Brown \& Levinson 1987), and the question is typically not even computed as such because it would be irrelevant in the context and likely be considered rude (Grice 1975).

As mentioned above, threats do not belong in the same category as requests (i.e., directives) but in the category of commissive speech acts, being a type of evil promise. Briefly put, for a promise to function suc- 
cessfully as a promise (for it to be 'felicitous') it must commit the speaker sincerely to a future act that the hearer wants to happen and that the speaker can actually carry out (Searle 2008 [1965]: 10-11).

The felicity conditions for a threat overlap with those of a promise in some respects but there are two critical differences: Firstly, the hearer (or reader) does not wish for the act to happen, and secondly, the speaker (or writer) does not need to intend to perform the action but only to make the hearer fear that s/he might. Further, I propose that the essential condition of a threat consists in an attempt to intimidate the hearer, rather than in committing the hearer to a course of action.

\begin{tabular}{|l|l|}
\hline $\begin{array}{l}\text { Propositional con- } \\
\text { dition }\end{array}$ & Speaker predicates a future act A \\
\hline $\begin{array}{l}\text { Preparatory condi- } \\
\text { tions }\end{array}$ & $\begin{array}{l}\text { (Hearer believes that) speaker is able to cause A to happen; } \\
\text { (Speaker believes that) Hearer does not wish A to happen }\end{array}$ \\
\hline Sincerity condition & $\begin{array}{l}\text { Speaker intends to (make Hearer believe he will) cause A } \\
\text { to happen }\end{array}$ \\
\hline Essential condition & $\begin{array}{l}\text { Speaker's utterance counts as an attempt to intimidate } \\
\text { Hearer }\end{array}$ \\
\hline
\end{tabular}

Table 2. The felicity conditions of a threat

Below, I present excerpts of threatening messages from Danish high and supreme court cases to illustrate how each of these felicity conditions are sufficient to evoke the illocutionary force of a threat - given the right circumstances, of course. There are definitely outlier cases in which it is difficult to determine that a threat has been made.

\section{Data material}

The data material for this study was collected through searches in a Danish database of judicial journals publishing important verdicts from the higher courts, i.e., verdicts that may set a precedent or change a prior legal position in Danish jurisprudence (Karnov Online). ${ }^{6}$ Out of 196 cases containing threatening speech acts, merely 22 concerned written messages. Spoken messages are not analyzed here since there is too much uncertainty concerning their exact wording: humans are surprisingly poor at remembering speech verbatim (Sachs 1967). A total of 68 written messages in-

6 Examples from this data set are referenced using the abbreviation of the judicial journals used in Karnov Online: TfK = Tidsskrift for Kriminalret ('Journal of Criminal Justice') and $\mathrm{U}=$ Ugeskrift for Retsvaesen ('Legal System Weekly'). 
dicted as threats under section 266 were extracted from these verdicts, and $75 \%$ of them were categorized as indirect threats.

\subsection{Indirect threats based on the propositional condition}

The propositional condition of a threat (see table 2) entails that a threat must concern a future act; you cannot threaten someone with something that has already happened (you can threaten to repeat it but then the repetition will take place in the future). And indeed, in some cases a reference to a future point in time is sufficient to evoke a threat (7).

(7) 2 timer igen (text message. TfK2016.1312)

2 hours again

'2 hours left'

The text message in (7) comes from a Danish stalking case where the writer sent several texts to his victim every or every other day, frequently referring to 'waiting for' her, 'getting' her or 'taking' her. In this context, declaring that there are '2 hours left' serves as a countdown, for instance to an unwanted meeting but possibly even to an attempted kidnapping. So, simply referring to a point in time two hours ahead from the time of writing suggests that something will happen to the addressee that she is not in control of and does not wish to happen.

Muschalik (2018: 77) cites a threat that refers to the future by hinting at a consequence of the addressee's possible actions:

(8) Yell at me again and see what happens

To see in this context means 'discover', which presupposes that the addressee does not already know what the consequence is. The relevant understanding of happens therefore must refer to a future event, something that has not already taken place. Notice, also, how both (7) and (8) completely omit any reference to a harmful act. This omission can be analyzed as a violation of the maxim of quantity (Grice 1975): the writer provides too little information and is likely intentionally underinformative. This invites inferences building on scripts about what might happen, and such scripts can sometimes be even more frightening than an actual mention of a harmful act. 


\subsection{Indirect threats based on the first preparatory condition}

As seen from table 2, there are two main preparatory conditions for successfully uttering a threat. The first concerns the threatener's ability to carry out the harmful act. There are obviously many different aspects related to this: being able to harm someone requires some sort of access to them (or to their loved-ones or belongings), it requires sufficient competence to perform the necessary steps needed to complete the act, and it may also require some technical or mechanical means. I exemplify each of these conditions below.

A recurring variant of having access to a victim depends on physical proximity $^{7}$, and I therefore call this the 'proximity condition'. Phrases appealing to the proximity condition are underlined in (9-10).

E, ,,,,,, JEG FINDER DIG OG NÅR JEG GØR SÅ ER DU SATME FÆRDIG MED AT GÅ RUNDT OG SPILLE LÆKKER [...] (Facebook. TfK2017.628]

E,,,,,,,, I FIND YOU AND WHEN I DO THEN ARE YOU BLOODY DONE WITH TO GO AROUND AND PLAY HOT [...]

'E [court's abbreviation of victim],,,,,, I WILL FIND YOU AND WHEN I DO YOU ARE BLOODY DONE PRANCING ABOUT PLAYING HOT [...] ‘

(10) Vent bare. Når du mindst venter det, så henter vi dig!! Om du er i lejligheden eller i bilen!! Enten det eller også får du snakket!!! (email. TfK2016.1312)

Wait just. When you least expect it, then get we you!! Whether you are in apartment-the or in car-the!! Either that or else get you talked!!! 'Just wait. When you least expect it, we'll get you!! Whether you are in your apartment or in your car!! Either that or you talk!!!'

In (9), the threatener presents a targeted effort to locate ('find') his victim and projects that her life circumstances will change dramatically as a consequence (she will no longer be able to 'play hot' when he has 'found'

\footnotetext{
7 Note that it is possible to go another step backwards in the chain of conditions that have to be met for a threatener to harm a victim: in order to come into physical contact with the victim, the threatener has to know where s/he is. An indirect threat referencing that aspect of the preparatory condition is Jeg ved hvor du bor 'I know where you live'- an utterance conventionalized as a threat to the extent that people recognize it as such even without supporting context (Bojsen-Møller et al., in prep).
} 
her). The specifics of how to ensure that outcome are left unmentioned, again violating the maxim of quantity. The threat in (10) exemplifies an even more domineering attempt to gain control over a victim by 'getting' her, i.e. physically taking her from the place she is in. Other aspects of this case supported an indictment for attempted kidnapping and duress but, notably, none of the 14 threatening messages mentioned what kind of harm the defendant had in mind.

Much less prevalent in my data set are appeals to the threatener's skills or competence to perform a harmful act, what I shall call the 'competence condition'. A good example is (11), where the Danish navy's special operations force (the underwater divers called the 'Frogman's Corps') is referenced as evidence of excellent battle skills.

(11) $[X X]$ er mit øgenavn fra frømandskorpset og bruger det kun når jeg skal i krig og kæmpe indtil døden! Kommer forbi. [XX] (sms. U.2005.2104)

$[\mathrm{XX}]$ is my nickname from Frogmanscorps-the and use it only when I must in war and fight until death-the! Come by. [XX] '[Sender's military nickname] is my nickname from the Frogman's Corps and I use it only when I go to war and must fight until death! Will stop by. [Sender's military nickname]'

Notice how (11) also contains a variant of the proximity condition in the elliptical clause Kommer forbi 'Will stop by', a phrase recognizable in other situations as a confirmation of a previous agreement to meet. Placed immediately after the reminder that the writer is a navy underwater diver and only uses his military nickname when going to war, it clearly is not a benign promise but the opposite; an evil promise, i.e. a threat.

In my data set, there are no instances of what I shall call the "means condition', i.e. having the technical, mechanical or other resources needed to perform the harmful act (see Rugala \& Fitzgerald 2003: 783 for a threat assessment perspective on this). However, this is exactly what we saw in Trump's tweet directed at Kim Jong-Un in (4) where he refers to his nuclear button and by extension to the US nuclear arsenal. Another example from an American context is (12), a letter sent to the White House in 2003 in response to an "upcoming change in interstate trucking regulations" (Gales 2010: 1). 
(12) If you change the hours of service on January 4, 2004 I will turn D.C. into a ghost town The powder on the letter is RICIN have a nice day Fallen Angel

As seen, the means to attain a harmful end here is the plant-based toxin ricin, which is fatal when ingested or inhaled in a sufficient dosage (https:// emergency.cdc.gov/agent/ricin/facts.asp).

\subsection{Indirect threats based on the second preparatory condition}

The second element of the preparatory condition is the addressee's lack of a wish to see the harmful act realized, exemplified in (13-14):

(13) $[\ldots]$ Du er gået langt over stregen ... du vil ikke ønske at opleve hvad der sker hvis du ikke betaler de penge ... (text message. TfK2008.431/2)

[...] You are gone far over line-the ... you will not wish to experience what there happens if you not pay money-the ...

'[...] You have so crossed the line ... you will not want to experience what happens if you don't pay that money back ...'

(14) Vi venter på dig i parken. Du får en slem overraskelse i aften! 26 kommer nok ikke til at ske for dig! (email. TfK2016.1312) We wait for you in park-the. You get a bad surprise to night! 26 comes probably not to to happen for you!

'We are waiting for you in the park. You'll get a nasty surprise tonight! 26 will likely not occur for you!' (mail. Tfk2016.1312)

The excerpt in (13) explicitly mentions that the addressee 'will not want' the unknown act to happen, and thereby attempts to frighten her into paying some sum of money if she is to avoid that consequence (note that this is one of the comparatively rare conditional threats). Likewise, the "nasty surprise' in (14) must refer to an unwanted event: the addressee was nearing her $26^{\text {th }}$ birthday at the time, so predicting that ' 26 will not occur for her' implies that the surprise is nasty in the sense that it has a fatal outcome.

\subsection{Indirect threats and the sincerity condition}

The status of the sincerity condition is disputed within speech act theory, and particularly so in the context of illegal speech acts. This is an exten- 
sion of the problem related to determining other people's intentions: If a speaker claims not to have been sincere in uttering a threat, will the utterance then not have functioned as a threat at all? Solan and Tiersma argue that a threatener "need only appear sincere. To be more exact, the speaker must intend the hearer to believe that the speaker intends to carry out the threatened act." (2005: 204; my italics).

In other words, the appearance of sincerity is an important prerequisite for a successful attempt to intimidate an addressee, but explicit claims to sincerity may have the opposite effect, actually making the threat less credible. Perhaps this explains why references to the sincerity condition are not widespread in our data. One of the rare examples is (15), which is in fact the initial part of the message excerpted in (13) above and seems to try to bolster the threat by asserting the threatener's 'seriousness'.

... mener det seriøst. Du er gået langt over stregen ... [...] (text message. TfK2008.431/2)

... mean it seriously. You are gone far over line-the ... [...]

'... am serious. You have so crossed the line ... [...]'

\subsection{Indirect threats and the essential condition}

References to the essential condition would consist in confessing to an attempt to intimidate the addressee, or, alternatively, that the utterance counts as a threat. I find no examples of this in the verdict data studied here, and invoking the essential condition seems to be a rare, if not unlikely, occurrence. Overall, I find it hard to see how an appeal to a speech act's essential condition can ever function as an indirect way of phrasing that same speech act. It would label the speech act rather than conveying it indirectly. In other data sets, we do see objections that "this is not a threat" - but this seems rather to be a violation of the maxim of quality (i.e. a lie), and therefore not an indirect threat but just a false labeling (see BojsenMøller et al., in prep.).

\section{Conclusion and perspectives}

A substantial majority of written threats tried at the higher courts in Denmark is phrased indirectly (at least according to verdicts that Danish legal journals have chosen to publish, where we find $75 \%$ to be indirect threats). On the one hand, this finding contradicts Fraser (1998) and others when they maintain that it is next to impossible to determine whether a threat has been made - even with indirect threats, the courts do not seem to waver. On 
the other hand, though, this study has only looked at threats that were successfully tried as such. It would be very valuable for both basic and applied research purposes to have access to alleged threats that were dismissed by the courts or not even investigated by police. Such data would allow for a comparison of the linguistic features in central and peripheral types of threats, and further, for assessing whether a linguistic analysis in terms of felicity conditions can assist the triers of fact in determining what counts as a threat and what does not.

Particularly in stalking cases it would be valuable to have better standards of evaluating threats. Stalking victims are frequently turned down by the justice system because it can be extremely difficult to prove that a threat has been made against them. The most cunning stalkers cloak their communications in polite, benign or even friendly words, but given a better understanding of the contextual and communicational conditions that pertain to threats, it may be easier to demonstrate that they are in fact attempts to dominate by intimidation.

\section{References}

Al-Shorafat, Mohammed O. 1988. Indirect threats. Word 39(3). 225-227. doi:10. 1080/00437956.1988.11435791.

Bojsen-Møller, Marie E., Sune Auken, Amy Devitt \& Tanya K. Christensen. In prep. Illicit genres: The case of threatening communications.

Brown, Penelope \& Stephen C. Levinson. 1987. Politeness: Some universals in language usage (Vol. 4). Cambridge: Cambridge University Press.

Catlin, Scott J. 1993. Proposal for regulating hate speech in the United States: Balancing rights under the international covenant on civil and political rights. Notre Dame Law Review 69(4). 771-813.

Christensen, Tanya K. \& Marie Bojsen-Møller. 2019. Sproglige virkemidler i indirekte trusler. Yonatan Goldshtein, Inger Schoonderbeek Hansen og Tina Thode Hougaard. (eds) 17. Møde om Udforskningen af Dansk Sprog.

Christensen, Tanya K. \& Marie Bojsen-Møller. 2018. Vi ved hvor du bor... Truslen som sproghandling og genre. Mål + Mcele 39(3). 25-30.

Coulthard, Malcolm, Alison Johnson \& David Wright. 2017. An introduction to forensic linguistics. Language in evidence. 2nd ed. London: Routledge.

Daniels, Jessie. 2008. Race, civil rights, and hate speech in the digital era. In Anna Everett (ed.), Learning race and ethnicity: Youth and digital media, 129-154. Cambridge: MIT Press. 
Fraser, Bruce. 1998. Threatening revisited. Forensic Linguistics 5(2). 159-173. doi:10.1558/s1l.1998.5.2.159.

Fuller, P. Brooks. 2015. Evaluating intent in true threat cases: The importance of context in analyzing threatening internet messages. Hastings Communications and Entertainment Law Journal 37(1). 37-78.

Gales, Tammy A. 2010. Ideologies of violence: A corpus and discourse analytic approach to stance in threatening communications. Davis: University of California PhD dissertation.

Gales, Tammy A. 2015a. The stance of stalking: a corpus-based analysis of grammatical markers of stance in threatening communications. Corpora 10(2). 171-200. doi:10.3366/cor.2015.0073.

Gales, Tammy A. 2015b. Threatening stances: a corpus analysis of realized vs. non-realized threats. Language and Law= Linguagem e Direito 2(2). 1-25.

Gingiss, Peter. 1986. Indirect threats. Word 37(3). 153-158. doi:10.1080/004379 56.1986.11435774.

Greve, Vagn, Asbjørn Jensen \& Gorm Toftegaard Nielsen. 2017. Kommenteret straffelov. Speciel del. Copenhagen: Jurist- og Økonomforbundets Forlag.

Grice, Herbert Paul. 1975. Logic and conversation. In Peter Cole \& Jerry L. Morgen (eds.), Syntax and semantics 3: Speech acts, 41-58. New York: Academic.

Harris, Sandra. 1984. The form and function of threats in court. Language \& Communication 4(4). 247-271. doi:10.1016/0271-5309(84)90010-7.

Henry, Jessica S. 2009. Beyond free speech: novel approaches to hate on the Internet in the United States. Information \& Communications Technology Law 18(2). 235-251. doi:10.1080/13600830902808127.

Karnov Online. https://pro.karnovgroup.dk/

Leets, Laura. 2001. Responses to internet hate sites: Is speech too free in cyberspace? Communication Law \& Policy 6(2). 287-317. doi:10.1207/ S15326926CLP0602_2.

Limberg, Holger. 2009. Impoliteness and threat responses. Journal of Pragmatics 41(7). 1376-1394. doi:10.1016/j.pragma.2009.02.003.

Muschalik, Julia. 2018. Threatening in English: A mixed method approach. Amsterdam: John Benjamins Publishing Company.

Nini, Andrea. 2017. Register variation in malicious forensic texts. International Journal of Speech, Language \& the Law 24(1). 99-126. doi:10.1558/ijsll.30173.

Pinker, Steven, Martin A. Nowak, \& James J. Lee. 2008. The logic of indirect speech. Proceedings of the National Academy of Sciences 105(3). 833-838. doi:10.1073/pnas.0707192105.

Rugala, Eugene A. \& James R. Fitzgerald. 2003. Workplace violence: From threat to intervention. Clinics in Occupational and Environmental Medicine 3(4). 775-789. doi:0.1016/S1526-0046(03)00117-1.

Sacs, Jacqueline S. 1967. Recognition memory for syntactic and semantic aspects of connected discourse. Perception \& Psychophysics 2. 437-442. doi:10.3758/ BF03208784. 
Searle, John R. 1979. A taxonomy of illocutionary acts. Expression and meaning: Studies in the theory of speech acts 1, 1-29. Cambridge: Cambridge University Press.

Searle, John R. 2008 [1965]. What is a Speech Act? In Ian Hutchby (ed.), Methods in language and social interaction 1, 1-16. Thousand Oaks: Sage Publications Ltd.

Shuy, Roger W. 1993. Language crimes: The use and abuse of language evidence in the courtroom. Cambridge: Blackwell.

Shuy, Roger W. 2010. The language of defamation cases. New York: Oxford University Press.

Shuy, Roger W. 2011. The language of perjury cases. New York: Oxford University Press.

Siegel, Michael L. 1998. Hate speech, civil rights, and the Internet: The jurisdictional and human rights nightmare. Albany Law Journal of Science \& Technology 9. 375.

Simons, André \& Ronald Tunkel. 2014. The assessment of anonymous threatening communications. J. Reid Meloy \& Jens Hoffmann (eds.), International handbook of threat assessment, 195-213. Oxford: Oxford University Press.

Solan, Larry \& Peter M. Tiersma. 2005. Speaking of crime, the language of criminal justice. Chicago: University of Chicago Press.

Yamanaka, Nobuhiko. 1995. On indirect threats. International Journal for the Semiotics of Law 8:2. 37-52. doi:10.1007/BF01677089. 